\title{
DESIGN CHOICE OF HIGH-PERFORMANCE MIXER FOR AJVAR/JAM USING THE TOPSIS MODEL
}

\author{
Anita Vasileva, Janko Jančevski, Kristina Jakimovska \\ Faculty of Mechanical Engineering, "Ss. Cyril and Methodius" University in Skopje, \\ P.O. Box 464, MK-1001, Skopje, Republic of North Macedonia \\ anita_vasileva@yahoo.com
}

\begin{abstract}
A b s t r a c t: People construct facilitating devices constantly, in order to keep pace with fast lifestyle, ones that will not change the way of preparing food, but contrarily will reduce the time required. Guided by the idea of simplifying the process of preparing homemade "ajvar"/jam, the aim of this paper is to give direction for a conceivable mixer design for "ajvar"/jam with reinforced performances from the mixers already available on the market. By analyzing and evaluating several available models, particles of the mixers will be compared, and thus possible changes will be made accordingly. The Multi-Criteria Analysis method (MCA) will be used to select the best solution.
\end{abstract}

Key words: mixer; Multi-Criteria Analysis method; TOPSIS (Technique for Order Preference by Similarity to Ideal Solution)

\section{ИЗБОР ЗА ПРОЕКТИРАњЕ ВИСОКОПЕРФОРМАНСНА МЕШАЛКА ЗА АЈВАР/ЏЕМ СО КОРИСТЕЊЕ НА МОДЕЛОТ ТОРSIS}

\begin{abstract}
А п с т р а к т: Со цел да се одржи чекор со брзиот начин на живот, а притоа да не се измени начинот на приготвување на храната, сѐ почесто се дизајнираат уреди кои го олеснуваат начинот на приготвување или пак го намалуваат времето потребно за готвење. Водени од идејата за упростување на процесот на приготвување на домашен ајвар/џем, целта на овој труд е да даде насока за можен дизајн на мешалка за ајвар/џем со подобри перформанси од досегашните мешалки достапни на пазарот. Преку анализирање и оценување на неколку достапни модели, направена е споредба на деловите од мешалките, а соодветно на тоа е даден предлог на можни измени. За селекција на најдоброто решение е искористен методот на повеќекритериумска анализа (MultiCriteria Analysis Method).
\end{abstract}

Клучни зборови: мешалка; метод на повеќекритериуска анализа; TOPSIS

\section{INTRODUCTION}

"Ajvar" is a traditional delicacy in the Balkans, which is found on almost every Macedonian table. Although it looks like "vegetable salad", the process itself is long and laborious. To get the idea of how it looks like, in several steps will be explained a typical ajvar preparing process:

Step 1: Wash and dry big red peppers and nice creamy eggplants.

Step 2: Grill them on low heat.

Step 3: Peel them thoroughly.
Step 4: Let them drain completely afterwards.

Step 5: Finely chop or grind your peeled vegetables.

Step 6: Place them in a wide, shallow, previously oiled cooking pot.

Depending on the quantity, the step 6 can take 3 or more hours, and "ajvar" is ready when all excess liquid evaporates, and the mass becomes thick and even.

"Ajvar" preparation is somewhat difficult, as it requires considerable manual labour, particularly to 
cook and stir for 3 or more hours. The difficulty is that a little negligence and insufficient stirring of the mixture can result a burned "ajvar".

Probably, that's the reason why Balkan people have been thinking how to ease this preparation process.

The "ajvar" blend machine offers mixing automatically, but it does not reduce the time needed for preparation. The major advantage of the mechanism is that it is easy to operate and is fully automated. The price of this device is normal and every interested buyer can afford it. Conclusively, the most important thing is safety, so this mechanism is totally safe if we follow the instructions for use.

This research paper will be divided into four parts:

- Part one: introduction, an overview of the research.

- Part two: current devices available on the market.

- Part three: Solution Selection (Using the Multi-Criteria Decision Making Models Method, with turning to: TOPSIS method).

- Part four: Analysis of the selected solution.

\section{THE OBJECTIVE OF THE PAPER}

The primary purpose of the mixers is to provide a better blend, to reduce the time needed for mixing and cut down manual labour. Many factors influence the quality of mixing, as physical properties of the material (density, shape, particle diameter, interactions, surface properties, cohesive forces, etc.), working conditions, construction and design of the mixers, etc [2].

Nowadays, testing of mixing efficiency is achieved by using sensors mounted inside the mixer, such as special cameras, which, through image analysis, determine the points where maximum homogeneity has been achieved [3].

\section{a) Influence factors of the mixing}

The properties of the particles them-selves have the greatest impact on the mixing process:

- the size of the particles and their shape;

- the chemical and physical properties of the particles.

To achieve mixing it is necessary to satisfy the two most important conditions:
- contact between the mixing components,

- pushing force to move the mixture.

The main parts of the blenders are the pot and the paddle blades. Homogenization of the mixture occurs as a result of rotating the paddle blades in the pot or rotating the pot and the paddle blades $[2,7$, 9].

The mixers that will be illustrated in this research paper are mixers where the pot does not move, but the paddle blades do. Generally, the rotation of the paddles can be around a vertical or horizontal axis, in the same or opposite direction. For "ajvar" mixers it is about paddles that rotate around a vertical axis in the same direction $[5,6]$.

.As it was mentioned in the preceding part, "ajvar" mixtures are designed to move and rotate the paddles around a vertical axis. The main purpose of these mixers is to mix the mixture (ajvar), but firstly to avoid burning.

In order to prevent the mixture from heating up and bakking, usually (depending on the load in the pan), the process takes several hours. For that period of time, the main purpose of the paddles is to completely move the ajvar mixture to the bottom of the pan and the sides. As it is a mixture of a certain density, special attention should be paid to the padding design, due to its loads and efficiency. On Figure 1 are shown seven models of mixers available on the market.

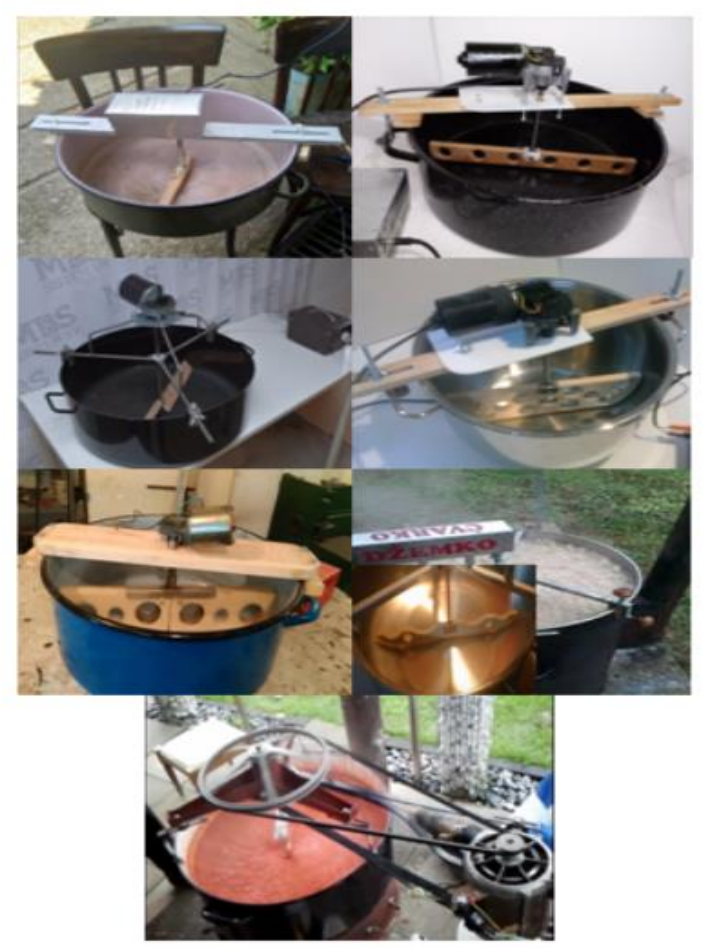

Fig. 1. Models of available ajvar mixers 
To summarize the data presented above, several graphs will be presented which compare the most important features between the seven shown models (Figures 2, 3, 4).

Almost all models (with the exception of Model 5 and Model 2) are flexible and adaptable to different diameters of pans. The main disadvantage is that the upper (structural part) is adaptable to different diameters but the paddles are not adaptable to different dimensions of the pans.

Another important thing is the paddles pressure. Each model has a different design solution to allow the paddle pressure. The most commonly used is a heavy-duty helical spring designed for compression and tension, with appropriate elastic rigidity (Figure 4).

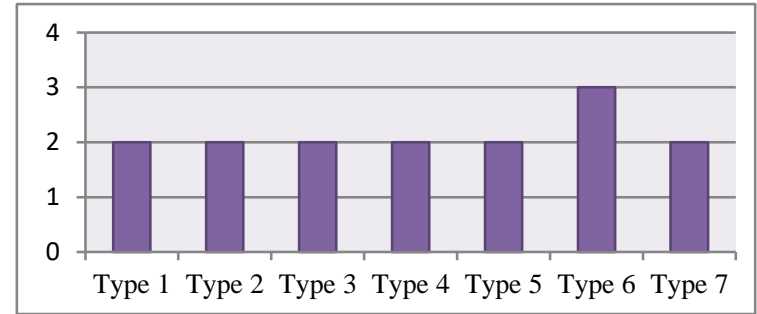

Fig. 2. Number of different usages

(only ajvar; ajvar and jam; ajvar, jam and for meat)

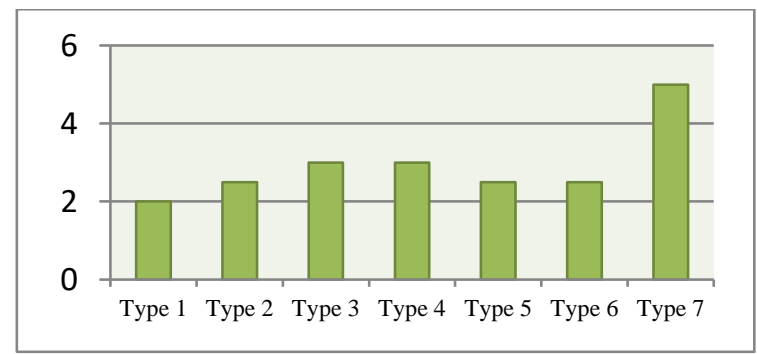

Fig. 3. Construction (easy, medium, difficult)

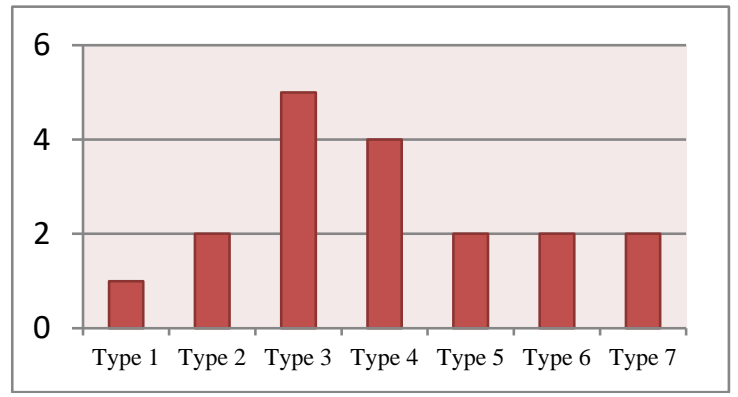

Fig. 4. Design of the peddels

\section{b) A list of requirements that the ajvar mixer needs to achieve}

From the models shown and the graphs comparisons of features, a list of requirements that an ajvar mixer should meet (Table 1).
Table 1

\section{List of requirements that an ajvar/jam mixter} should achieve

\begin{tabular}{l}
\hline 1. Easy switch on \\
2. Easy switch off \\
3. Easy to operate \\
4. Multipurpose \\
5. Solid construction \\
6. Easy mounting \\
7. Does not damage the pan \\
8. Not harmful to the product - the mixture (ajvar, jam, etc.) \\
9. Affordable price \\
10. Fits to all types of pans \\
11. Reduced hand force \\
12. Safety for operate
\end{tabular}

\section{SELECTION OF THE BEST MODEL}

Multi-criteria decision (TOPSIS) will be used in order to be selected as the best solution, comparing three models, which are selected as alternative ajvar/jam mixer solutions.

\section{MODEL A:}

Advantages:

1. Simple construction, average price.

2 . The construction allows adjustment to the dimensions of the pan.

Disadvantages:

1. The dimensions (length) of the paddles cannot change (not adjustable for different pans dimensions).

\section{MODEL B:}

Advantages:

1. The construction allows adjustment to the dimensions of the pan.

2. The dimensions (length) of the paddles can be changed (adjustable for different pans dimensions).

Disadvantages:

1. The cost would be higher than Model A.

\section{MODEL C:}

Advantages:

1. The construction allows adjustment to the dimensions of the pan.

2. The dimension (length) of the paddles can be changed (adjustable for different pans dimensions).

Disadvantages:

1. The cost and complex construction. 


\section{RESULTS AND DISCUSSION OF IMPLEMENTATION THE MCDM METHODS (TOPSIS)}

The Multi-Criteria Decision-Making (MCDM) is an important potential tool for analyzing complex problems. In this paper, the TOPSIS method is used [3]. TOPSIS (Technique for Order Preference by Similarity to Ideal Solution) is designed as an alternative to the ELECTRE method and can be considered as one of its most widely accepted variants [7].

There are some steps which represent TOPSIS method procedure.

To introduce the MCDM method, as one of the ways that offers us the ranking of the best model of the three selected, we will show the three alternatives (Model A, Model B and Model C) and four criteria $\left(\mathrm{C}_{1}, \mathrm{C}_{2}, \mathrm{C}_{3}, \mathrm{C}_{4}\right)$ that the continuation is given (Table 2) [1].

\section{Table 2}

\section{Represents TOPSIS information}

\begin{tabular}{c|cccc}
\hline \hline \multirow{2}{*}{ Alternatives } & \multicolumn{5}{|c}{ Criteria } \\
\cline { 2 - 5 } & $\mathrm{C}_{1}$ & $\mathrm{C}_{2}$ & $\ldots$ & $\mathrm{C}_{j}$ \\
\hline $\mathrm{A}_{1}$ & $X_{11}$ & $X_{12}$ & $\ldots$ & $X_{1 j}$ \\
$\mathrm{~A}_{2}$ & $X_{21}$ & $X_{22}$ & $\ldots$ & $\mathrm{X}_{2 j}$ \\
. & $\cdot$ & $\cdot$ & $\cdot$ & $\cdot$ \\
$\cdot$ & $\cdot$ & $\cdot$ & $\cdot$ & $\cdot$ \\
$\cdot$ & $\cdot$ & $\cdot$ & $\cdot$ & $\cdot$ \\
$\mathrm{A}_{\mathrm{i}}$ & $X_{\mathrm{i} 1}$ & $X_{\mathrm{i} 2}$ & $\ldots$ & $X_{i j}$ \\
$\mathrm{~W}$ & $W_{1}$ & $W_{2}$ & $\ldots$ & $W_{j}$ \\
\hline \hline
\end{tabular}

Where [1]:

$\mathrm{A}_{1}, \mathrm{~A}_{2}, \ldots, \mathrm{A}_{j}$ represent possible alternatives among which a decision maker has to choose,

$\mathrm{C}_{1}, \mathrm{C}_{2}, \ldots, \mathrm{C}_{j}$ are criteria with which alternative performance are measured,

$\mathrm{x}_{\mathrm{ij}}$ is rating of alternative $\mathrm{A}_{\mathrm{i}}$ with respect to the criteria $\mathrm{C}_{j}$,

$\mathrm{w}_{\mathrm{j}}$ is the weight of the criteria $\mathrm{C}_{\mathrm{j}}$,

$i=1, \ldots, m$ is the number of alternatives,

$j=1, \ldots, n$ is the number of criteria [1].

When some of the criteria are shown as the qualitative values, they need to be changed into quantitative values. For that purpose is used a numerical scale shown in (Table 3 ).
Table 3

Transformation of linguistic scales into quantitive values

\begin{tabular}{lcc}
\hline \hline \multirow{2}{*}{ Linguistic scale } & \multicolumn{2}{c}{ Quantitative value } \\
\cline { 2 - 3 } & Benefit $-\max$ & Cost $-\min$ \\
\hline Very high & 9 & 1 \\
High & 7 & 3 \\
Average & 5 & 5 \\
Low & 3 & 7 \\
\hline \hline
\end{tabular}

For presenting the MCDM methods, as one of the possible ways of ranking the solutions, are chosen three alternatives $\left(A_{1}, A_{2}, A_{3}\right)$ and four evaluating criteria $\left(\mathrm{C}_{1}, \mathrm{C}_{2}, \mathrm{C}_{3}, \mathrm{C}_{4}\right)$, which are mentioned above. Qualitative data in Table 3 are changed into quantitative Table 4. To make a normalized decision matrix is calculated by the eq. (1). It is shown in Table 5 [7].

$$
\bar{X}_{i j}=\frac{X_{i j}}{\sqrt{\sum_{j=1}^{n} X_{i j}^{2}}}
$$

Ta ble 4

\section{Row data}

\begin{tabular}{|c|c|c|c|c|}
\hline Alternatives & $\begin{array}{l}\text { Ũ } \\
0 \\
0 \\
0 \\
\vdots \\
0\end{array}$ & 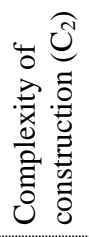 & 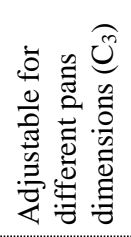 & 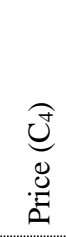 \\
\hline & $\max$ & $\min$ & $\max$ & $\min$ \\
\hline M. A & 7 & 5 & 7 & 5 \\
\hline M. B & 5 & 5 & 5 & 5 \\
\hline M. C & 5 & 7 & 5 & 7 \\
\hline Weighting factor & 0.25 & 0.25 & 0.35 & 0.15 \\
\hline
\end{tabular}

T a b le 5

Calculated weighted normalized matrix $v_{i j}$

\begin{tabular}{ccccc}
\hline & $\mathrm{C}_{1}$ & $\mathrm{C}_{2}$ & $\mathrm{C}_{3}$ & $\mathrm{C}_{4}$ \\
& $\max$ & $\min$ & $\max$ & $\min$ \\
\hline $\mathrm{A}_{1}$ & 0.18 & 0.18 & 0.176 & 0.075 \\
$\mathrm{~A}_{2}$ & 0.13 & 0.18 & 0.127 & 0.075 \\
$\mathrm{~A}_{3}$ & 0.13 & 0.25 & 0.126 & 0.105 \\
\hline
\end{tabular}


In step two, calculation of weighted normalized matrix $v_{i j}$ of each criterion is made using the following eq. (2):

$$
v_{i j}=\bar{X}_{i j} \times W_{j}
$$

Step three (Table 6) is calculation of the ideal best (formula (3)) and ideal worst (formula (4)) value. In step four, we calculated the Euclidean distance from the ideal best $\left(\mathrm{S}_{\mathrm{i}}^{+}\right)$, formula (5), and ideal worst $\left(\mathrm{S}_{\mathrm{i}}^{-}\right)$, formula (6), value [3]. The results are shown in (Table 7).

$$
\begin{gathered}
V^{+}=\left(v_{1}^{+}, v_{2}^{+}, \ldots, v_{n}^{+}\right)= \\
=\left[\left(i \max v_{i j} \mid j \in I\right),\left(i \min v_{i j} \mid j \in J\right)\right] \\
V^{-}=\left(v_{1}^{-}, v_{2}^{-}, \ldots, v_{n}^{-}\right)= \\
=\left[\left(i \min v_{i j} \mid j \in I\right),\left(i \max v_{i j} \mid j \in J\right)\right] \\
S_{i}^{+}=\left[\sum_{j=1}^{m}\left(v_{i j}-v_{j}^{+}\right)^{2}\right]^{0.5} \\
S_{i}^{-}=\left[\sum_{j=1}^{m}\left(v_{i j}-v_{j}^{-}\right)^{2}\right]^{0.5}
\end{gathered}
$$

Table 6

Calculation of the ideal best $\left(V^{+}\right)$ and ideal worst $\left(V^{-}\right)$value

\begin{tabular}{ccccc}
\hline \hline & $\mathrm{C}_{1}$ & $\mathrm{C}_{2}$ & $\mathrm{C}_{3}$ & $\mathrm{C}_{4}$ \\
& $\max$ & $\min$ & $\max$ & $\min$ \\
\hline $\mathrm{A}_{1}:$ & 0.04 & 0.06 & 0.04 & 0.01 \\
$\mathrm{~A}_{2}:$ & 0.03 & 0.06 & 0.03 & 0.01 \\
$\mathrm{~A}_{3}:$ & 0.03 & 0.09 & 0.03 & 0.02 \\
$V^{+}$ & 0.04 & 0.06 & 0.04 & 0.01 \\
$V^{-}$ & 0.03 & 0.09 & 0.03 & 0.01 \\
\hline \hline
\end{tabular}

T a b l e 7

The Euclidean distance from the ideal best $\left(S_{i}^{+}\right)$, and ideal worst value $\left(S^{i-}\right)$

\begin{tabular}{cccccccc}
\hline \hline & $\mathrm{C}_{1}$ & $\mathrm{C}_{2}$ & $\mathrm{C}_{3}$ & $\mathrm{C}_{4}$ & & \\
& $\max$ & $\min$ & $\max$ & $\min$ & $S^{+}$ & $S^{-}$ \\
\hline $\mathrm{A}_{1}$ & 0.04 & 0.06 & 0.04 & 0.01 & 0.025 & 0.031 \\
$\mathrm{~A}_{2}$ & 0.03 & 0.06 & 0.03 & 0.01 & 0.018 & 0.025 \\
$\mathrm{~A}_{3}$ & 0.03 & 0.08 & 0.04 & 0.02 & 0.031 & 0 \\
$V^{+}$ & 0.04 & 0.06 & 0.04 & 0.01 & & \\
$V^{-}$ & 0.03 & 0.09 & 0.03 & & & \\
\hline \hline
\end{tabular}

The last step in implementation of TOPSIS method is calculation of performance score, formula (7) [3]. The results are shown in the Table 8.

$$
P_{i}=\frac{s_{i}^{-}}{S_{i}^{+}+S_{i}^{-}} \text {. }
$$

Table 8

Calculation of performance score

\begin{tabular}{ccc}
\hline \hline$S^{+}$ & $S^{-}$ & $P_{i}$ \\
\hline 0.025 & 0.03007 & 0.55491 \\
0.018 & 0.02504 & 0.58491 \\
0.030 & 0 & 0 \\
\hline \hline
\end{tabular}

In the end, a rank of the $\mathrm{P}_{i}$ value is made (Table 9) [3]. From Table 9 is concluded that the ideal option, in this example, is alternative no. 2.

Table 9

Rank of the $P_{i}$ value

\begin{tabular}{cccc}
\hline \hline$S^{+}$ & $S^{-}$ & $P_{i}$ & Rank \\
\hline 0.024623 & 0.030699 & 0.55491 & 2 \\
0.017767 & 0.025035 & 0.58491 & 1 \\
0.030699 & 0 & 0 & 3 \\
\hline \hline
\end{tabular}

\section{DISCUSSION ABOUT THE BEST SOLUTION}

By using TOPSIS, Model B was selected (Alternative 2) as the best solution. In this part will presented a CAD model of the parts and assemblies. In addition will be shown images of the prototype during the process period.

During the prototype construction, initially we made a construction with three profiles and an electric motor and a reducer mounted in the middle (Figure 5). In this research paper would not be shown more details about the power feed. Dimensions of the three welded profiles are: $15 \times 15 \mathrm{~mm}$ and length $70 \mathrm{~cm}$ (Figure 5). In order to obtain an assembly that can be mounted above the pan/pot and for easier carrying and packing, on the profiles were made cuts which allow to move them horizontal. The third profile does not have this capability because it has two vertical short profiles on which the box is mounted (inside the box are the reductor and electromotor) (Figure 6). 


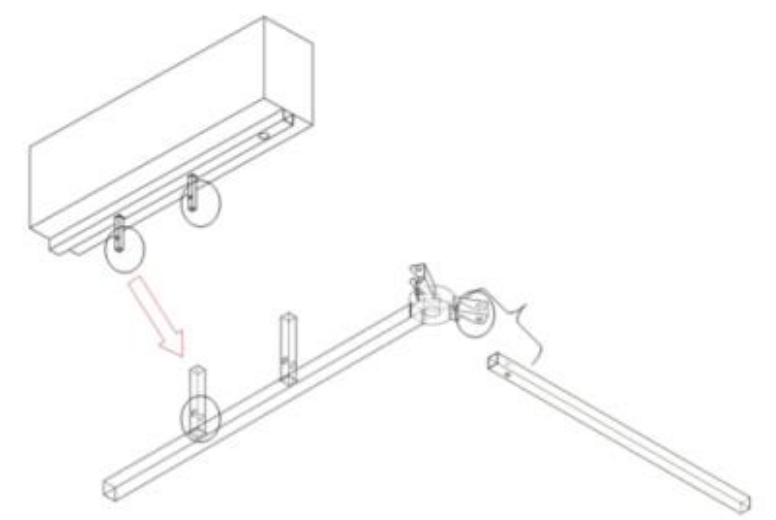

Fig. 5. Assembly of reductor-box and construction

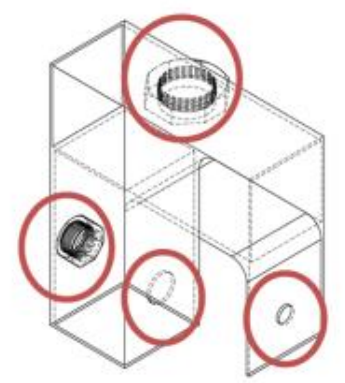

Fig. 6. Diameter regulate mechanism

As it will be used for food purposes, profiles require being stainless steel by HACCP standards. The shaft is stainless steel, with $d=10 \mathrm{~mm}$ (Figure 7B). On the shaft, there are holes (to adjust the height of the paddles, corresponding to the different pan/pot models). Two gaskets and a spring are mounted on the shaft to pressure the paddles. The paddles are made by silicon rubber which would allow better clears on the bottom (Figure 7C). The rails of the two paddles (profiles $15 \times 15$, inox) are welded on the both sides of the profile $20 \times 20 \mathrm{~mm}$. The middle profile $(20 \times 20 \mathrm{~mm})$ has $15 \mathrm{~mm}$ hole in the middle to insert the shaft. On the rails there are holes (relation: screw and nut) (Figure 7A) to fit the silicone rubber to adjust the length of the silicone rubber. On the frame there are three mechanisms (one for each $15 \times 15 \mathrm{~mm}$ profile), that will regulate the setting up corresponding to the diameter of the pan (Figure 7). After the calculations (not shown in this study) [6, 7], and according to the CAD model, the parts were assembled and tested. To be testing credible it requires the pan to be filled with "ajvar" or other mixture. Currently such testing is not made. The testing that is made shows whether during the rotation the paddles move the mixtures and if the adjustment to the diameter of the pan/pot is feasible. The testing was done with water.

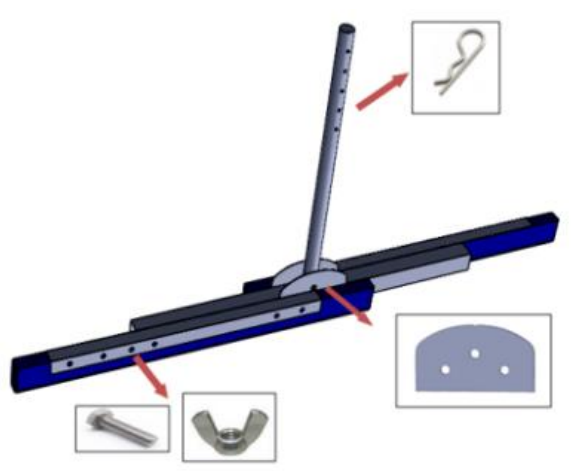

A)

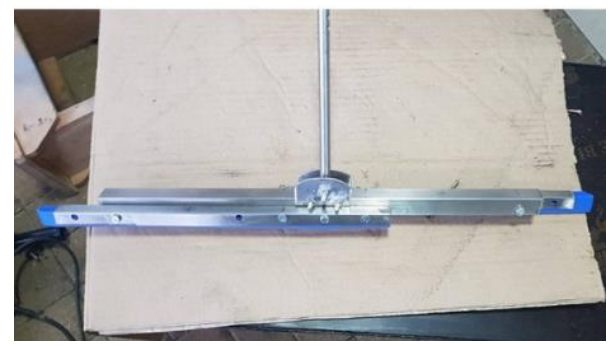

B)

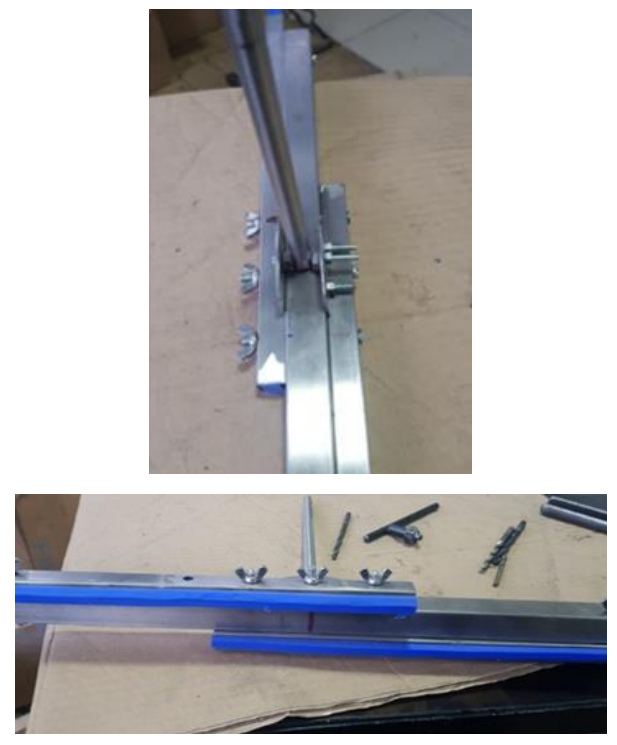

C)

Fig. 7. A) CAD model of the paddle. B) Prototype model. C) Part of paddle prototype model

The inital construcion had flaws and the profiles were not well centered. To solve this problem, a new construction was made. On the second test, another defect was noticed, namely a sound that was not from the silicon rubber but from the rotary shaft. We have found that the welded profiles are not at a $90^{\circ}$ angle and comes in scraping or sound creation. To eliminate it, the paddle was completely changed. This construction is simpler than previous version and fully meets the requirements during testing. 


\section{CONCLUSION}

As a conclusion to this research paper, we have analyzed the ideal solution for an ajvar/jam mixer. SWOT analysis is a strategic planning method used to evaluate the strengths, weaknesses, opportunities and threats involved in a project [10]. The SWOT analysis firstly starts with determining the end state or goal [8]. The word SWOT contains the initials of the English words: Strengths, Weaknesses, Opportunities and Threats [9]. Strengths distinguish the project (model B) by the competitors [8]. Weaknesses are features that put the project (model B) in a subordinate role to other models available so far [10]. Opportunities are future improvements that can be made to improve the model [9]. Threats are external elements in the environment that could cause problems [10]. Identification of SWOT analysis is essential. Strengths: The model B allows adjustment to different diameters and depths of a pan. It is made of material by HACCP standards. It is easy to assemble and does not require a lot of space. Weaknesses: Can only be used for mixing "ajvar" and maybe jam. Threats: Pans with angles greater than 90 degrees. In this case, the edges of the paddles will not touch the vertical sides, as they are not designed like that. Opportunities: Temperature sensors that according to the temperature of the stove will give information to increase or decrease the torque.

\section{REFERENCES}

[1] Jakimovska, K.: Development of methodology for condition based vehicle assessment (Doctoral dissertation), "Ss. Cyril and Methodius" University in Skopje, Faculty of Mechanical Engineering, Skopje, 2013.
[2] Hristov, D. D.: Construction and Road Machines (4th edition), Technique, Sofia, 1974.

[3] Jančevski, J.: Transportation Devices, "Ss. Cyril and Methodius" University in Skopje, Faculty of Mechanical Engineering, Skopje, 2003.

[4] Sammut-Bonnici, T.: Wiley Encyclopedia of Management, John Wiley \& Sons Ltd, 2015.

[5] Cullen, P. J.: Food Mixing: Principles and Applications, Blackwell Publishing Ltd., 2009.

[6] Fellows, P.: Food Processing Technology - Principles and Practice (Second edition), Woodhead Publishing Limited, 2000.

[7] Pavić, Z., Novoselac, V.: Notes on TOPSIS method, International Journal of Research in Engineering and Science (IJRES), Vol. 1, No. 2, pp. 5-12 (2013).

[8] Singh, R. P., Heldman, D. R.: Introduction to Food Engineering (Forth edition), Elsevier Inc., 2009.

[9] Paul, L. P., Atiemo-Obeng, V. A., Kresta, S. M.: Handbook of Industrial Mixing: Science and Practice, John Wiley \& Sons, Inc., 2004.

[10] Okwabi, R.: Design and construction of a hand operated mixer machine for food fortification, International Research Journal of Engineering and Technology (IRJET), Vol. 3, No. 9, pp. 6-15 (2016).

[11] Okafor, B. E.: Design of power driven dough mixing machine, International Journal of Engineering and Technology, Vol. 5, No. 5, pp. 76-79 (2015).

[12] Gürel, E., Tat, M.: SWOT analysis: A theoretical review, Journal of International Social Research, Vol. 10, No. 51, pp. 994-1006 (2017).

[13] Kalkani, E. C., Boussiakou, L. G., Boussiakou, I. K.: Students' SWOT analysis in mechanics of materials determines the action planes for students and instructor, World Transactions on Engineering and Technology Education, Vol. 3, No. 2, pp. 217-222 (2004).

[14] Coman, A., Ronen, B.: Focused SWOT: Diagnosing critical strengths and weaknesses, International Journal of Production Research, Vol. 47, No. 7, pp. 5677-5689 (2009). 
